\title{
BALTASAR DE ECHAVE IBIA
}

\author{
Some Critical Notes on the \\ Stglistic Charactex of His Art
}

B Y

\section{G I B S ON DA NES}

I $N$ this paper I should like to discuss the work of a seventeenth century Mexican painter; Baltasar de Echave Ibja. Because there is so little known about this artist and because very little recognition has been given his works, I should like to discuss his painting from a critical point of view in order to give him the place he deserves in the history of colonial art in Mexico. I should like also to make some suggestions as to his antecedents and origins in order that his own accomplishments might better be understood.

There were three painters in this family of artists who bore the name of Baltasar de Echave; the elder one, Orio; his son, Echave Ibia, with 
whom we are primarily concerned; and his son, Echave Rioja. Of the three, Echave Ibia was the least famous, but now emerges as one of the most important from the standpoint of artistic quality. All of the notes on Mexican colonial painting up to the last few years mentioned only the other two. It was not until recently that Echave Ibia emerged as a separate individual, when D. Manuel Toussaint pointed out the separate identity of this painter from the other members of the same family. ${ }^{1}$ Echave Ibia has been neglected by historians and critics partly because he was so little known in his own time. As is so often the case, he suffered from being the son of a famous father. Part of the later historic submersion is due also to the fact that he was given no large, important commissions. Most of his works are very small, some of the finest ones being no larger than fifteen by twenty inches. Since most of the writers on Mexican colonial painting in the nineteenth and early twentieth century were more impressed by quantity and size than by stylistic quality, he has not been considered important, and often has not been considered at all.

As a result of this neglect during his lifetime, the biographical data about him is slim indeed. In fact, neither his birth date nor the exact date of his death is known. By piecing together the date of his father's marriage in Mexico, the date of his own marriage, and the dates on his works, along with the facts known about his son, Echave Rioja, it may be fairly well established that he was born in the latter part of the sixteenth century, began painting in the early decades of the seventeenth, and concluded his career near the middle of the same century. The date of his earliest painting is 1620 . The latest date on a painting is 1640 . Most of what is known is that which may be inferred from his works.

Since Echave Ibia began his training in the art of painting during the carly years of the seventeenth century, it may be well to go into the stylistic factors which may have shaped his own development. As was natural, he studied with his father, Echave Orio, as did other of the more talented painters in Mexico. The early works of Echave Ibia reflect very definitely the influence of the father.

1 Catálogo de Pinturas: Sección Colonial. Publication of Mrseo Nacional de Arte: Plásticas (México: Ediciones del Palacio de Bellas Artes, 1934) formed by D. Manuel Toussaint.

This was the first time in this century that the works of Echave Ibia appear separate from the other members of the family. Before this there is but a notice given by $D$. Carlos de Sigüenta Gongota in the reventeenth ceatury. 
His father was perhaps the best known and most admired painter in Mexico at this time. He must have been, from all accounts, quite a remarkable man. He was not only talented as a painter but as a writer and a linguist. In 1607 he wrote a book on the Basque language. ${ }^{2}$

He came to Mexico directly from the northern province of Guipuzcoa. There is no evidence of his having painted before coming to Mexico, but a painter from the same province, Francisco de Ibia, called Zumaya, had to come to Mexico in 1565. The elder Echave studied with him and began producing works in his own shop toward the end of the century. Echave Orio contributed a great deal to the development of painting in Mexico. Although he did not begin work until he was quite mature, he was intelligent and prodigious in his output. He endowed the art with a monumentality and impressiveness that painting had not possessed in Mexico up to his time.

His work reflects the Italianate manner rather than the HispanoFlemish style. Whether or not he spent much time in Madrid or Seville on his way to take the boat to Mexico is not known. At any rate, the aristocratic taste in Spain was leaning heavily on borrowed Italianisms through Luis de Vargas, who painted the altarpiece in the Cathedral at Seville. The full force of Italinate manners was introduced by the artists who were decorating the Escorial for Philip. This is particularly true of the mannerists that Philip brought into Spain, Tibaldi, Zuccarro, Cambiaso. A change, however, took place when Philip had the Titians that he owned moved to the new palace. Navarrete, El Mudo, was more closely drawn to Titian than to the mannerists, and worked in a strong Titianesque vein until his death in 1579. The successor to Luis de Vargas in Seville, Juan de las Roelas, was also more closely drawn to the painting of northern Italy and Venice than to the Romanism of the mannerists. Italianate ideas also came in by the devious of the Netherlands with Pedro de Campana in Seville.

All of this is by way of background to show that the painting of the two Echaves was conditioned by the strong tendency toward Italian ideas which had for the most part been taken from Venice and northern Italy.

2 Discursos de la antigüedad dr la lengua cantabre baecongada, compuestos por Baltasar de Echave. natural de la Villa de Zumaya. en la Provincia de Guipúztoa 7 vecino de México. (Con licencia y privilezio en México: Imprenta de Enrico Martinex, Ano de 1607.) Then is a portraic of Eehave in the frootiepiect. engraved in wood. 
There were undoubtedly examples of Venetian school paintings in Mexico at this time. ${ }^{3}$ Engravings of paintings by the Venetians were probably circulated and known by the painters of Mexico. The sobering influence of the black shadow school developed by Ribalta and carried on by Ribera and Zurbaran dit not greatly affect the Mexican artists until the middle of the century.

The instruction that the elder Echave received was that of a diluted Italianate sort from Francisco de Zumaya. His ideas for compositions and the handling of various themes were probably taken from engraving of Italian paintings. Considering the fact that he did not have the traditional long apprenticeship in his youth, his achievement in painting is remarkable, but his art, when looked at objectively, is often rhetorical with theatrically posed figures in awkwardly scaled architectural settings. In his best works, he does achieve a simplicity and sense of largeness.

The style that his son, Baltasar de Echave Ibia, developed is surprisingly different. Some of these distinctions may be pointed out. First. his color is quite unlike that of his father or any of the other painters in Mexico. Whereas his father, Orio, preferred the warmer tones of sienna and umber, Ibia worked in cool grays, gray greens, and a rich variety of blue. Second, Echave Ibia made one of the most effective uses of landscape in his religious paintings of almost any other painter in colonial times. Landscape becomes a vital part of the whole expression, as it did with the Venetians. Third, his brushwork was unique in his sensitivity to the subtle graduations of tone. There is little abrupt and sudden modelling. He controlled passages in an exquisite way. . Fourth, his whole concept of design and arrangement was genuinely organic in this relating foreground to background. His sense of form was plastic in a truly painterly manner.

One of the earliest works of Echave Ibia is that of the Immaculate Conception, dated 1620 , and it indicates that he was already growing independent of his father's way of painting. In his treatment of one of the favorite themes in Spanish art, he employed a rich decorative pattern showing the Virgin replendently bejeweled against a background of gold

3 There was an equestrian portrait of Charles $\mathrm{V}$ by $T$ ítian hanging at the Vice regal Palace in 1666, according to the deacription by Sariñana. This painting has disappeared but was vimilar to the one now at the Museo del Prado in Madrid. This note is to be found in. El Llanto de Occidente en el ocaso del mas claro sol de las Espafias, description of the funeral of Philip IV in 1666 , by Dr. Isidro Saritiana. quoted by Artemio de Valle-A tizpe, El Palacio Nacional de México. (México, 1934.) 
that was further enhanced by the blue of the clouds and the vista below. The relative degree of two-dimensionality of the figures that are only slightly modelled, and the flat brilliance of the background gives the effect of a refulgent tapestry. This emphasis upon linear design and the delicate modelling in light and dark is quite different from Echave Orio's manner of painting. In this early work, one is able to see Echave Ibia's ability to organize complicated and diverse groups of forms in a very satisfying fashion. This work is much more linear and clear in contour than his mature production. Later he became more truly "painterly". in his conception of form. He already showed his preference for the cool tones that were typical of his later work. The types that he employed were taken from his father's style, but the sensitive arrangement of cherubs, attributes, and the brocaded Virgin was his own contribution.

By the time that he painted the picture St. John the Baptist (Fig. 1), more of his typical qualities appeared. The color scheme in this work showed definitely his propensity for cool tones. The actual handling of the paint and the development of tonal transition, too, was tending toward a maturer conception. Although this work is indicative of transition, the artist had attained a competent degree of mastery of his medium.

Weaknesses appear in his ability to integrate the figure with the lamb and the landscape in the distance. In this work the picturesque landscape remained very much merely the usual recipe. The landscape is present chiefly as a kind of romantic embellishment of the whole design. Certain parts of it, however, particularly the mountains in the distance and the sky are vigorously brushed in. It is important for its treatment and the more brilliant, clear coloration. The sudden break between the left arm holding the staff and the forms of forest, stream, and waterfall made for an awkward and incongruous relationship. Also the attributes of St. John, the nimbus, lamb, and the inscription floating from the staff, secm to be there out of necessity instead of becoming a logical part of the whole formal pattern. This rather awkward disposition of forms becomes apparent when it is contrasted with the detail of the head of St. John and the view of the blue mountain in the distance. This detail shows clearly his capable technical abilities. The head is simply and solidly modelled. Also the clarity and beauty of color is well displayed. The graved sulphuric yellow of St. John's shirt is a most effective complement to the bright blue of the background. In fact, this detail isolates those aspects of his expression. that are most personal and distinctive. 
One of Echave Ibia's most dramatic canvases is that of the repentant Mary Magdaten. (Fig. 2).) It is much more closely integrated in idea and form than the St. John we have just seen. In this work, the artist has created a very convincing portrayal of the grieving woman. The characterization, in pose, gesture, and attitude rings true. Here a simplicity of arrangement coupled with strong contrasts of illumination tells the story in a most effective manner. The half-length figure, the large dark mass marking off the middle ground, the trees, and sky in the distance, are all reminiscent of traditions from northern Italy. The lighting of the figure and drapery that is strongly set out against the mass of the background models the forms in a strong and powerful manner. The forms of figure and drapery are well articulated with the landscape setting. He used none of the picturesque artificiality of the St. John, but in this picture the sky streaked with thin lines of clouds helps to reinforce the mood and spirit of the whole piece.

By comparing this with versions of the same theme by two European painters, it is apparent how much less mannered Echave Ibia's conception is. The Magdalen, done by Bernard van Orley, in the sixtenth century shows the same features of half-length figure and landscape, employed in a truly manneristic fashion. There is nome of the dramatic emphasis of the Echave Ibia painting. The artist was interested in miniscular and painstaking textural effects, not in actual content. Another picture by a minor Spanish painter, Luis de Carvajal, who worked on the decoration of the Escorial, also shows a very mannered and empty treatment. He used a similar arrangement of the Magdalen set against a large mass of foliage with the sky opening beyond, but the total effect is artificial and strained when it is compared to Ibia's treatment.

The most striking weakness of Ibia in this work is that of drawing. It is apparent here in the rubbery delineation of hands and neck. Despite this, however, the fingers and hands are treated as a part of the whole desing pattern, establishing a fluent linear relationship with the larger movement of arms and drapery. This tends to alleviate the lack of searching draftsmanship.

Another weakness of the artist appears in two small paintings, a Crucifirion (1637, Fig. 3), and Christ Bearimg the Cross. (1633, Fig. 4.)

4 These paintings, in the collection of don Salvador Ugarte, are the onIy ones that have been found that wofll Echave lbia working with large groups of figures. It is likely that these two belong to a eries of the Stations of the Crome 
DOI: http://dx.doi.org/10.22201/iie.18703062e.1942.9.320

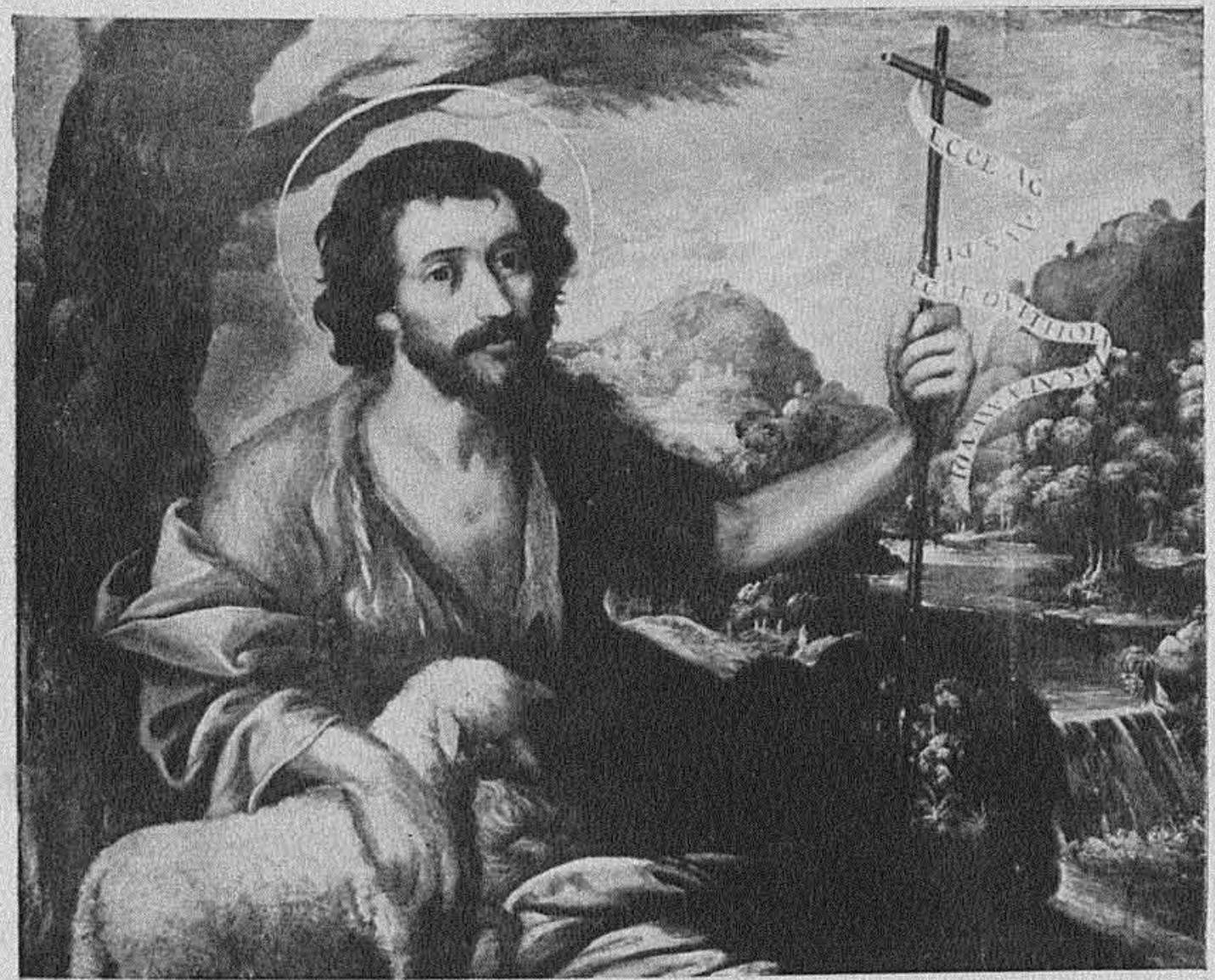

1. B. de Echave Ibia. St. John the Baptist,-Galleries of S. Carlos. México. 
DOI: http://dx.doi.org/10.22201/iie.18703062e.1942.9.320

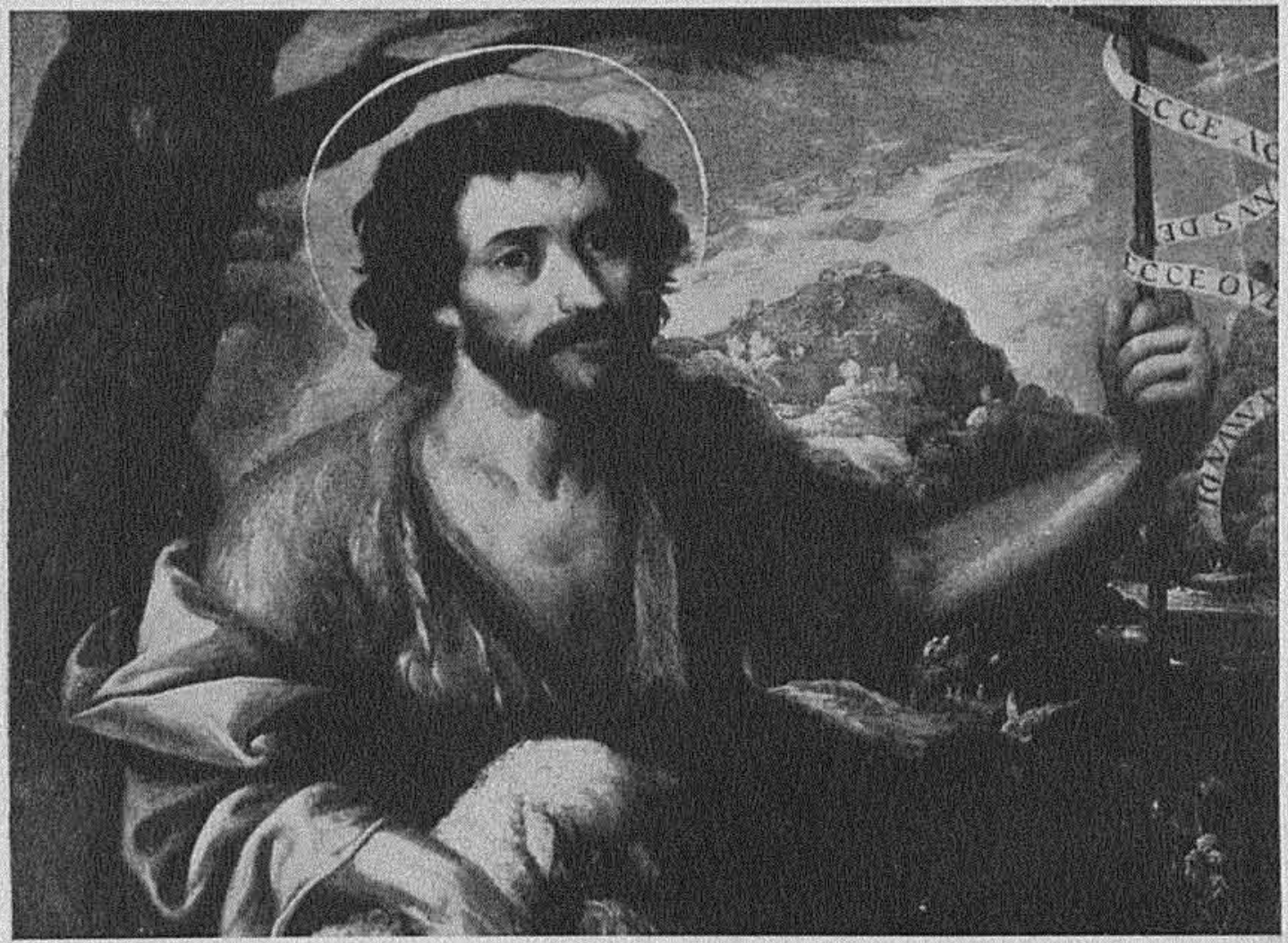

1 bis. St. John the Baptist. Detail. 
DOI: http://dx.doi.org/10.22201/iie.18703062e.1942.9.320

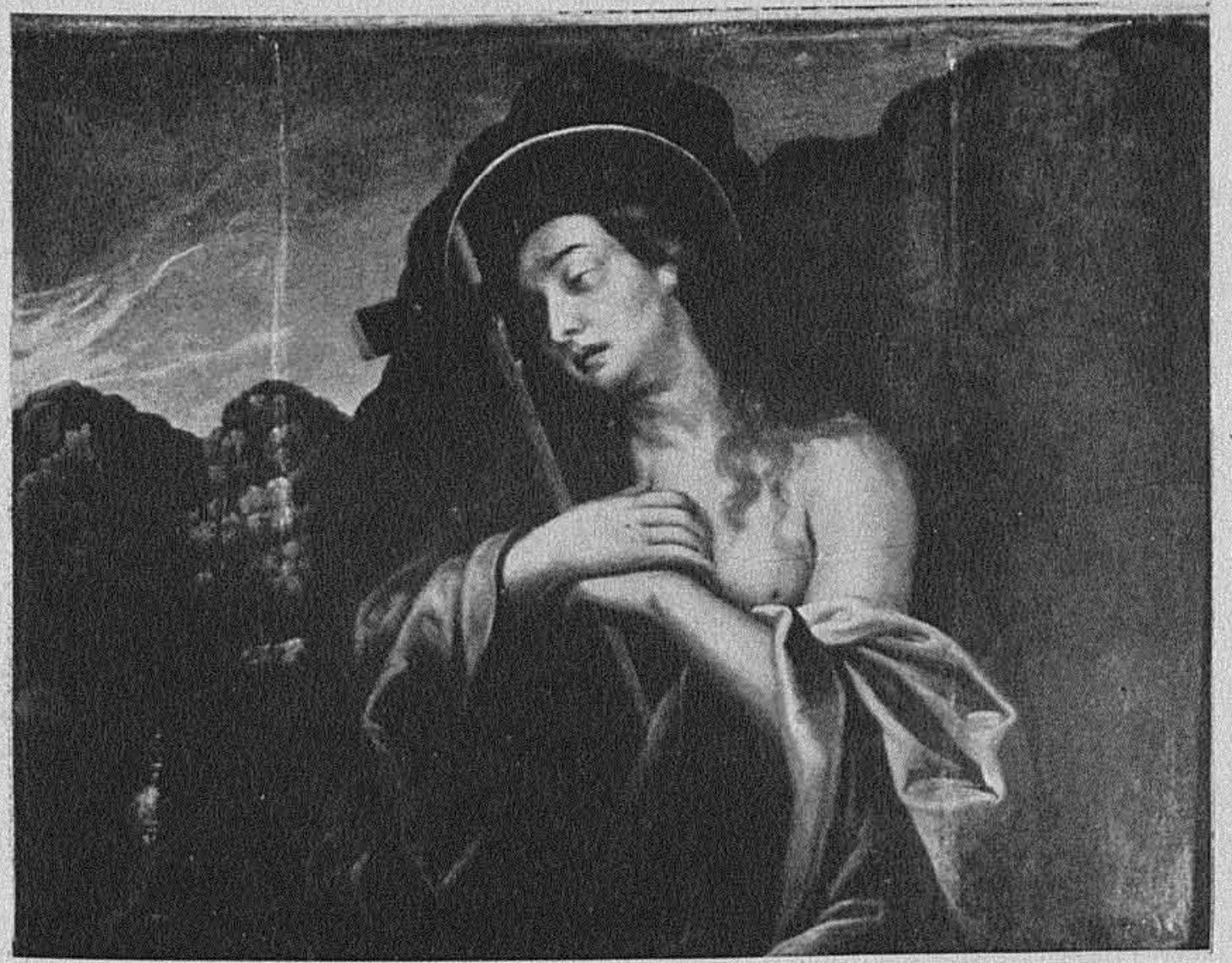

2. B. de Echave Ibia. Mary Magdalene. Oil on wood.-Galleries of S. Carlos. México. 


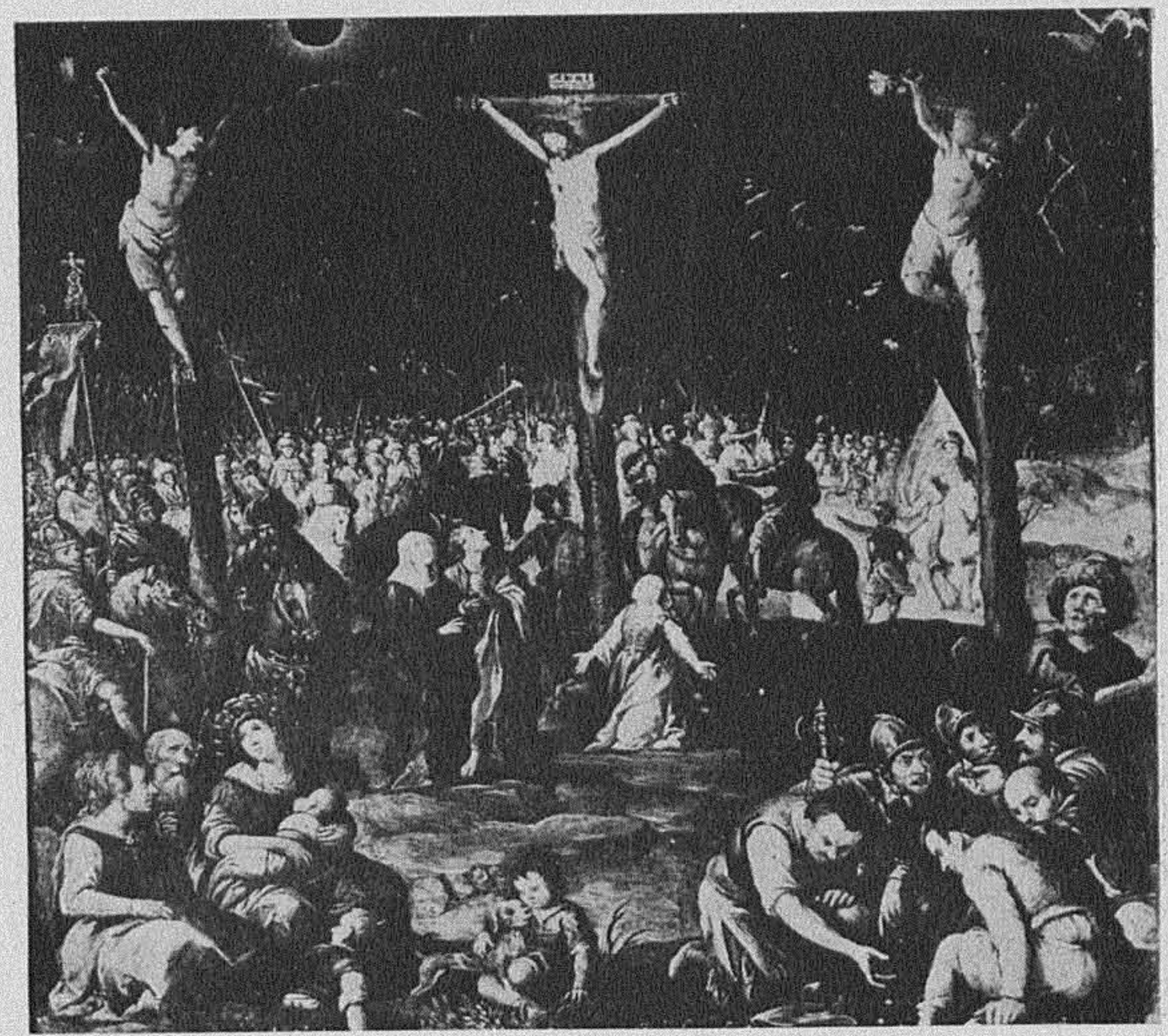

3. B. de Echave Ibia, Crucifixion-Collection of Sr. Salvador Ugarte. México. 
DOI: http://dx.doi.org/10.22201/iie.18703062e.1942.9.320

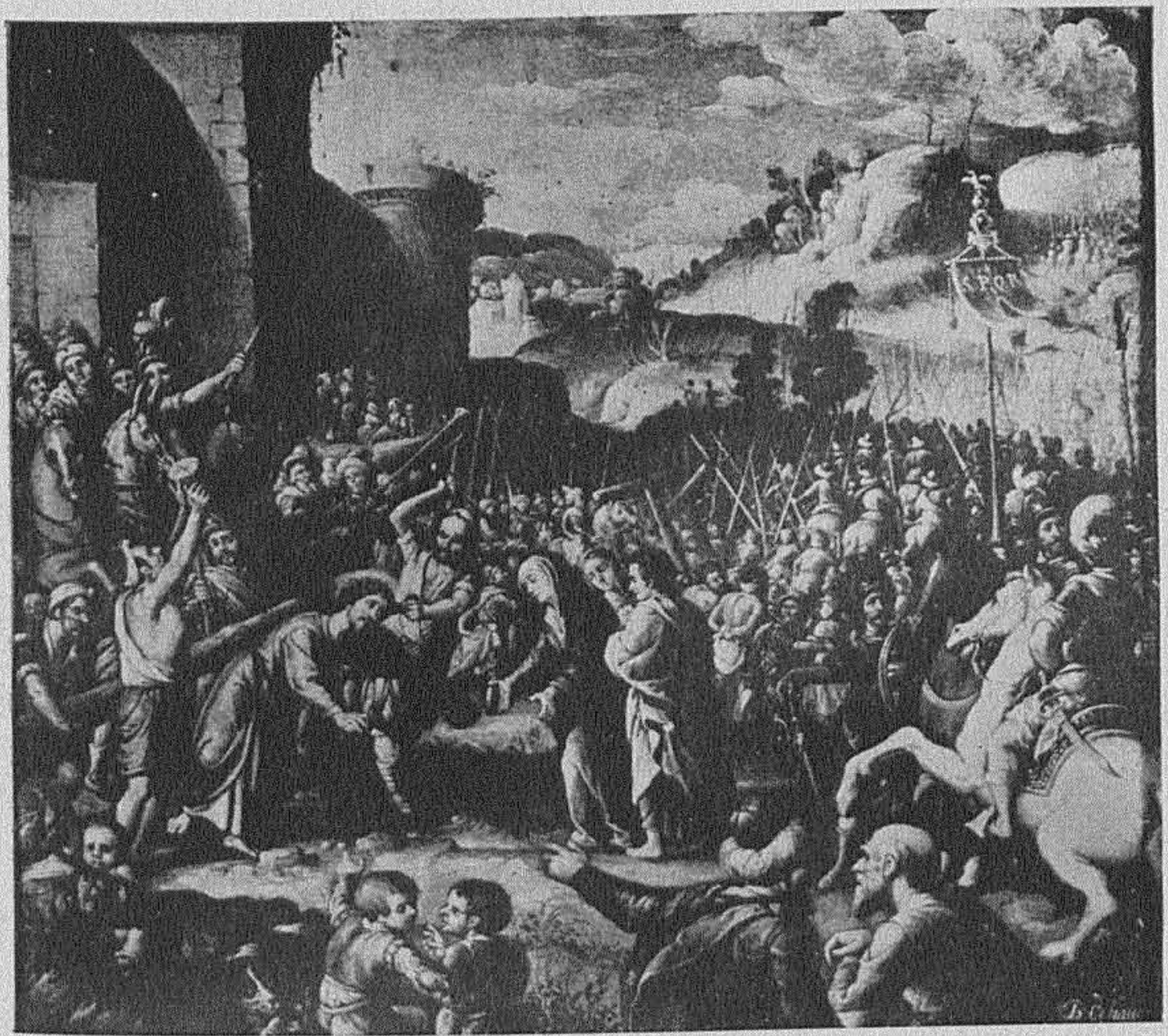

4. B. de Echave Ibia. Christ Bearing the Cross.-Collection of Sr. Salvador Ugarte. México. 
DOI: http://dx.doi.org/10.22201/iie.18703062e.1942.9.320

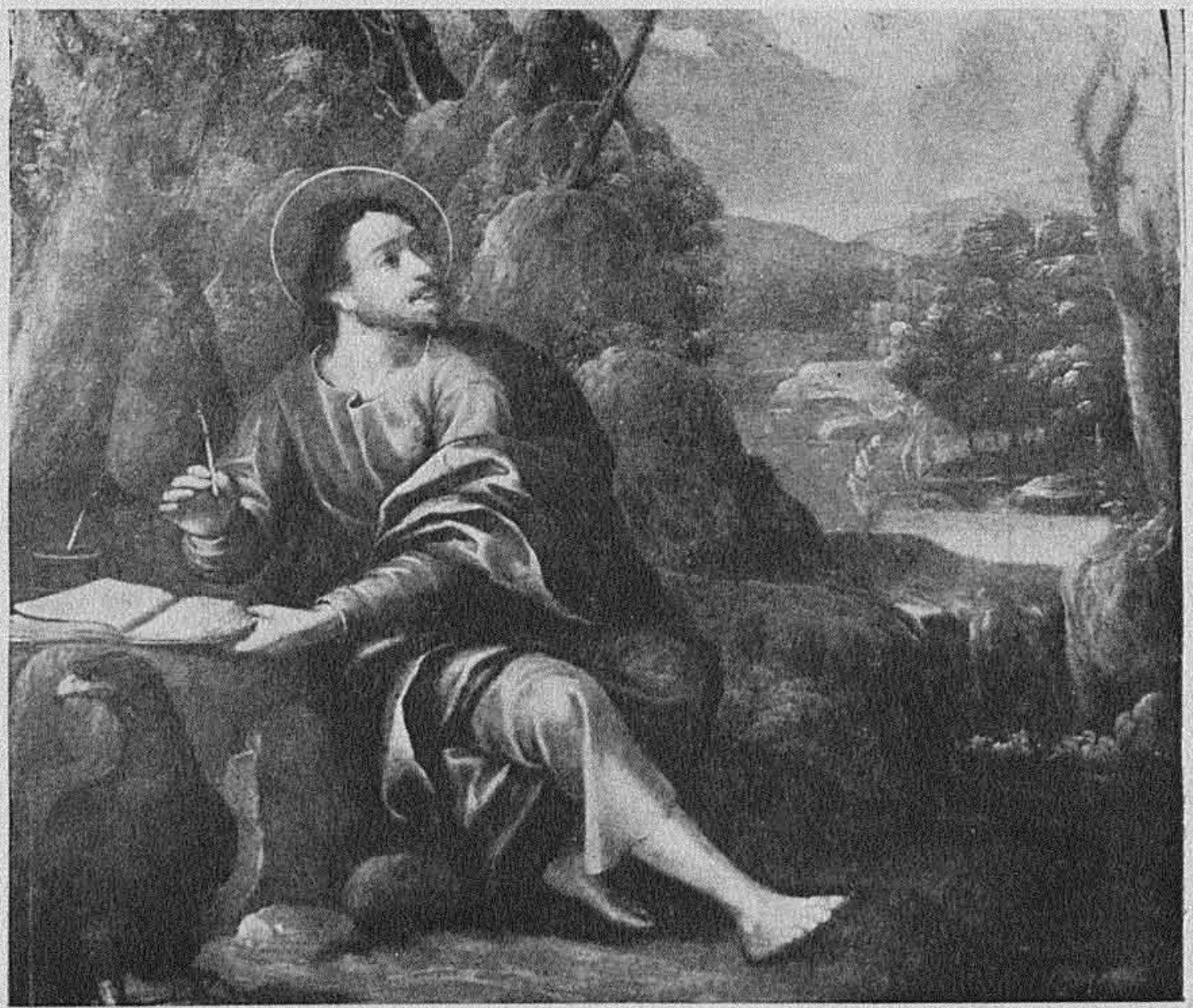

5. B. de Echave Ibia. St. John Evangelist.-Galleries of S. Carlos. México. 
DOI: http://dx.doi.org/10.22201/iie.18703062e.1942.9.320

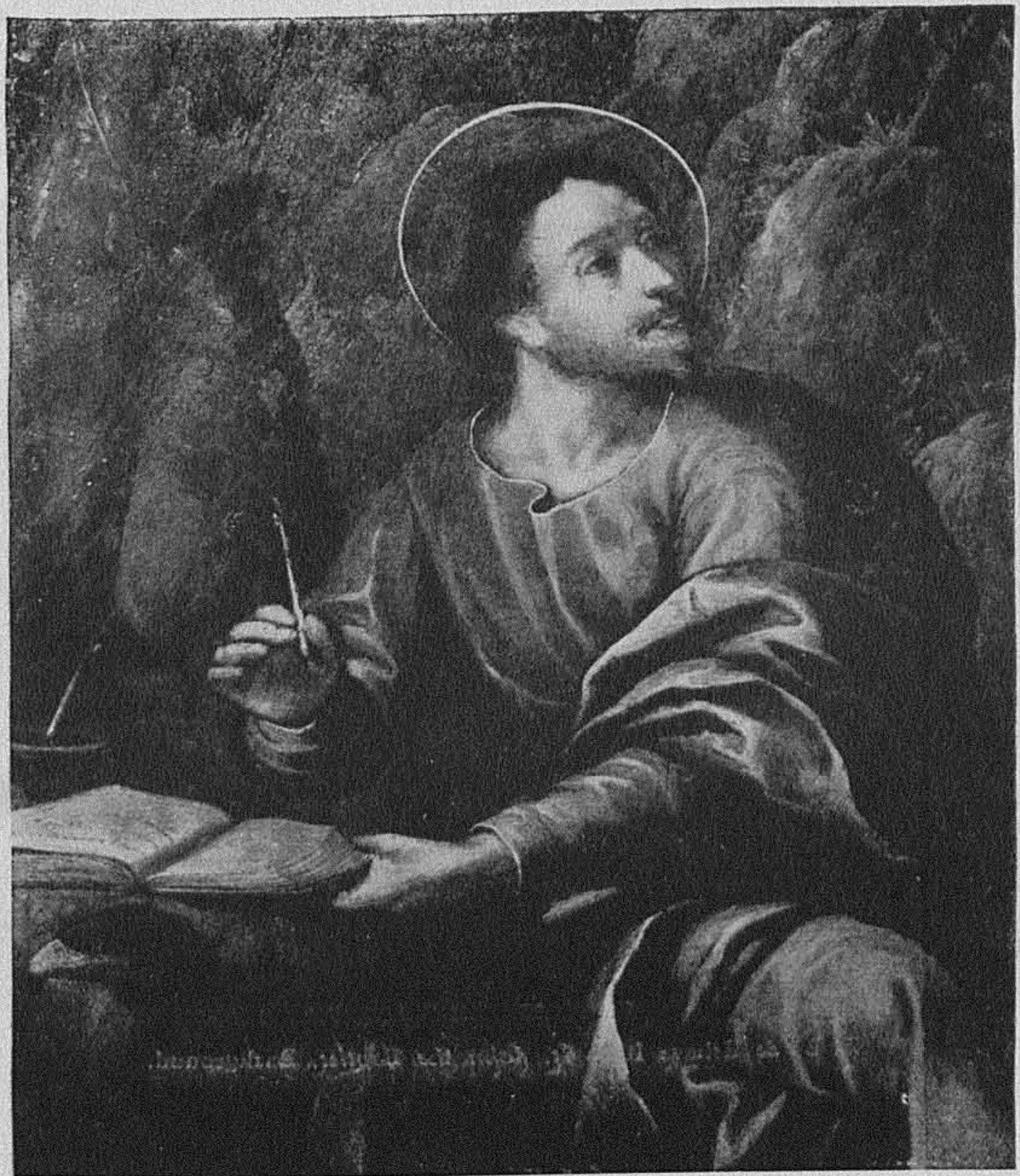

6. B. de Echave Ibía. St. John Evangelist. Detail. 
DOI: http://dx.doi.org/10.22201/iie.18703062e.1942.9.320

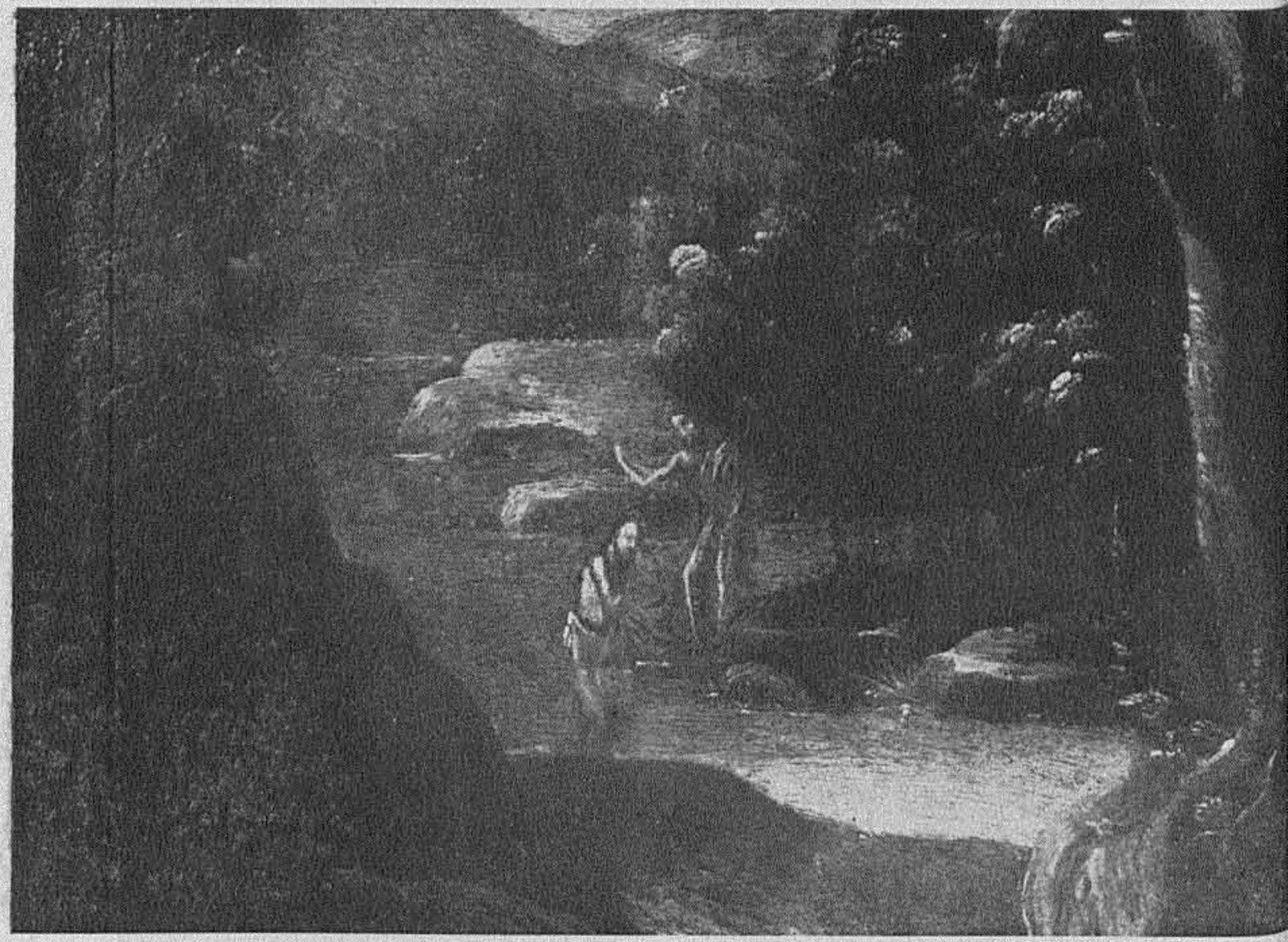

7. B. de Echave Ibia. St. John the Baptist. Background. 
DOI: http://dx.doi.org/10.22201/iie.18703062e.1942.9.320

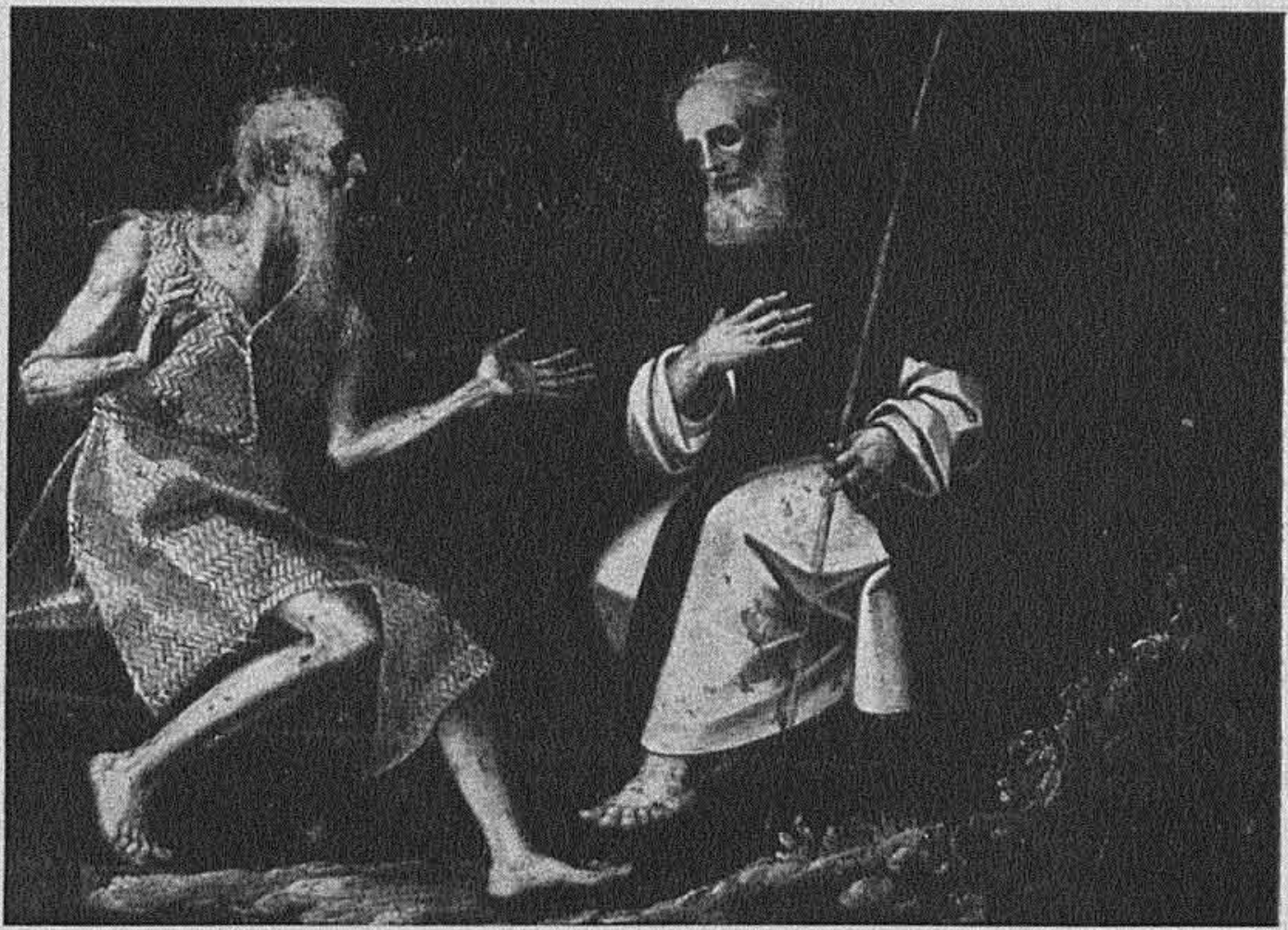

9. B. de Echave Ibia. St. Paul and St. Anthony. Detail. 
DOI: http://dx.doi.org/10.22201/iie.18703062e.1942.9.320

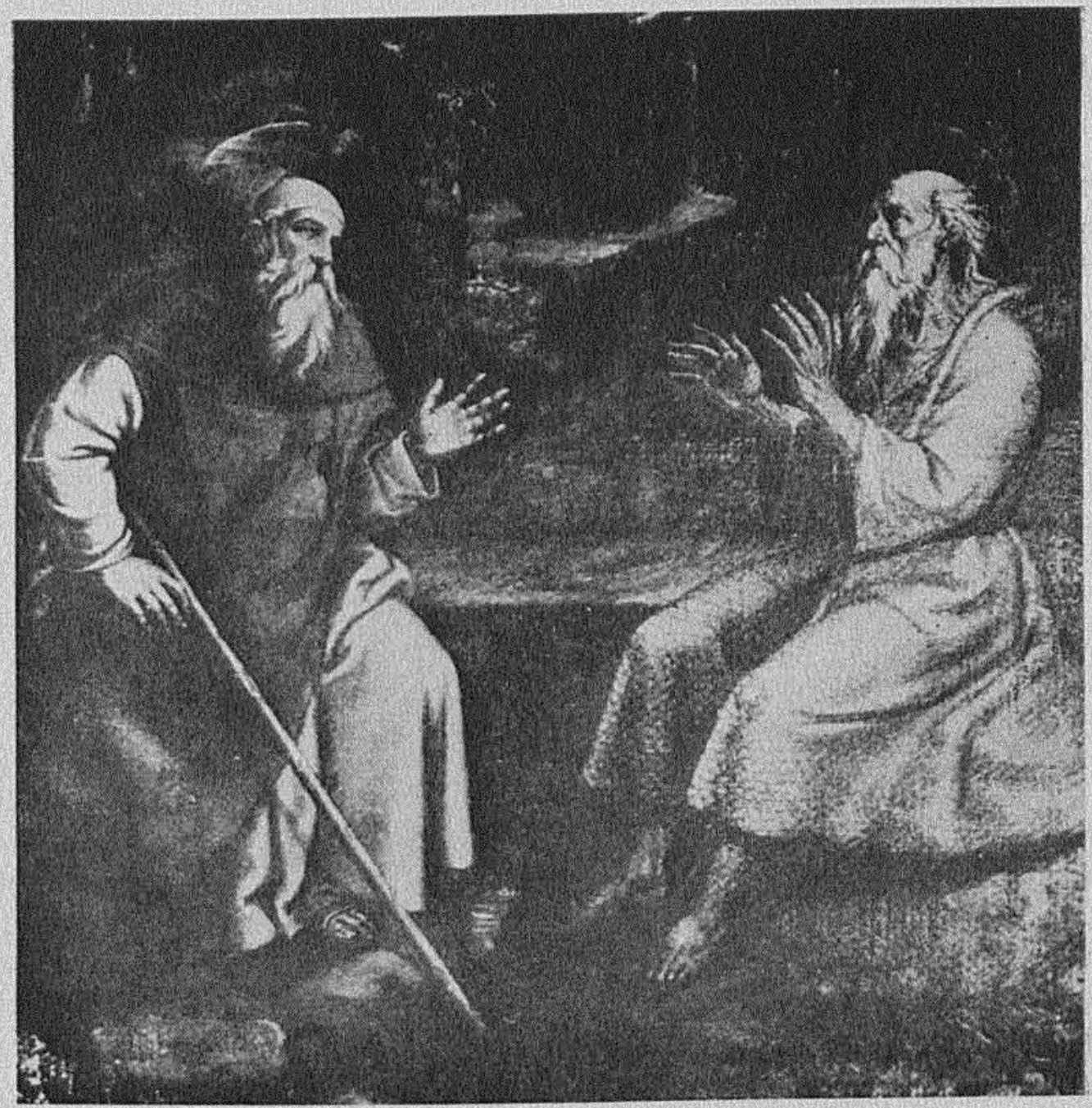

10. Sánchez Coello. St. Paul and St. Anthony. 
DOI: http://dx.doi.org/10.22201/iie.18703062e.1942.9.320

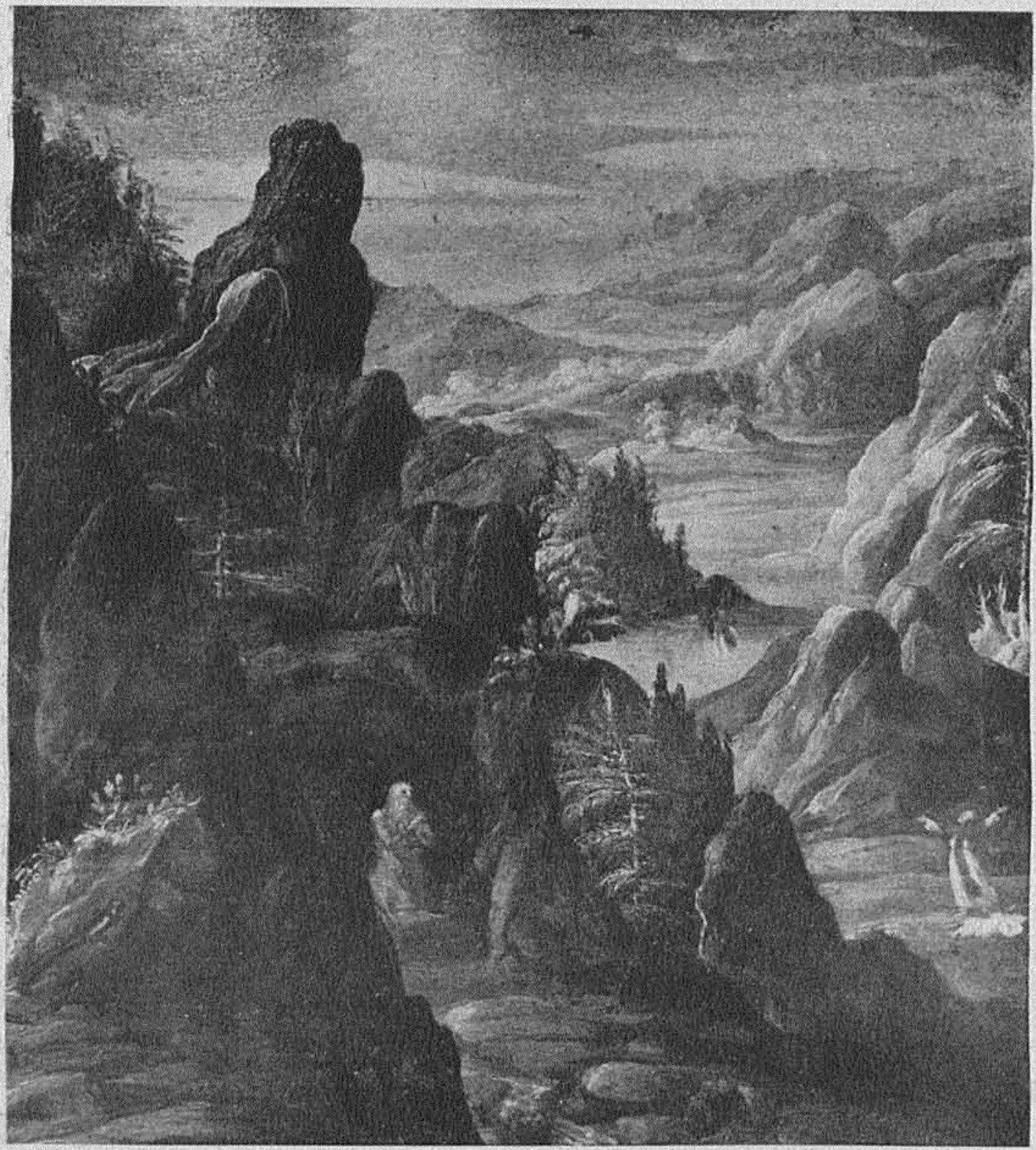

11. B. de Echave Ibía. St. Paul and St. Anthony in the Desert. 


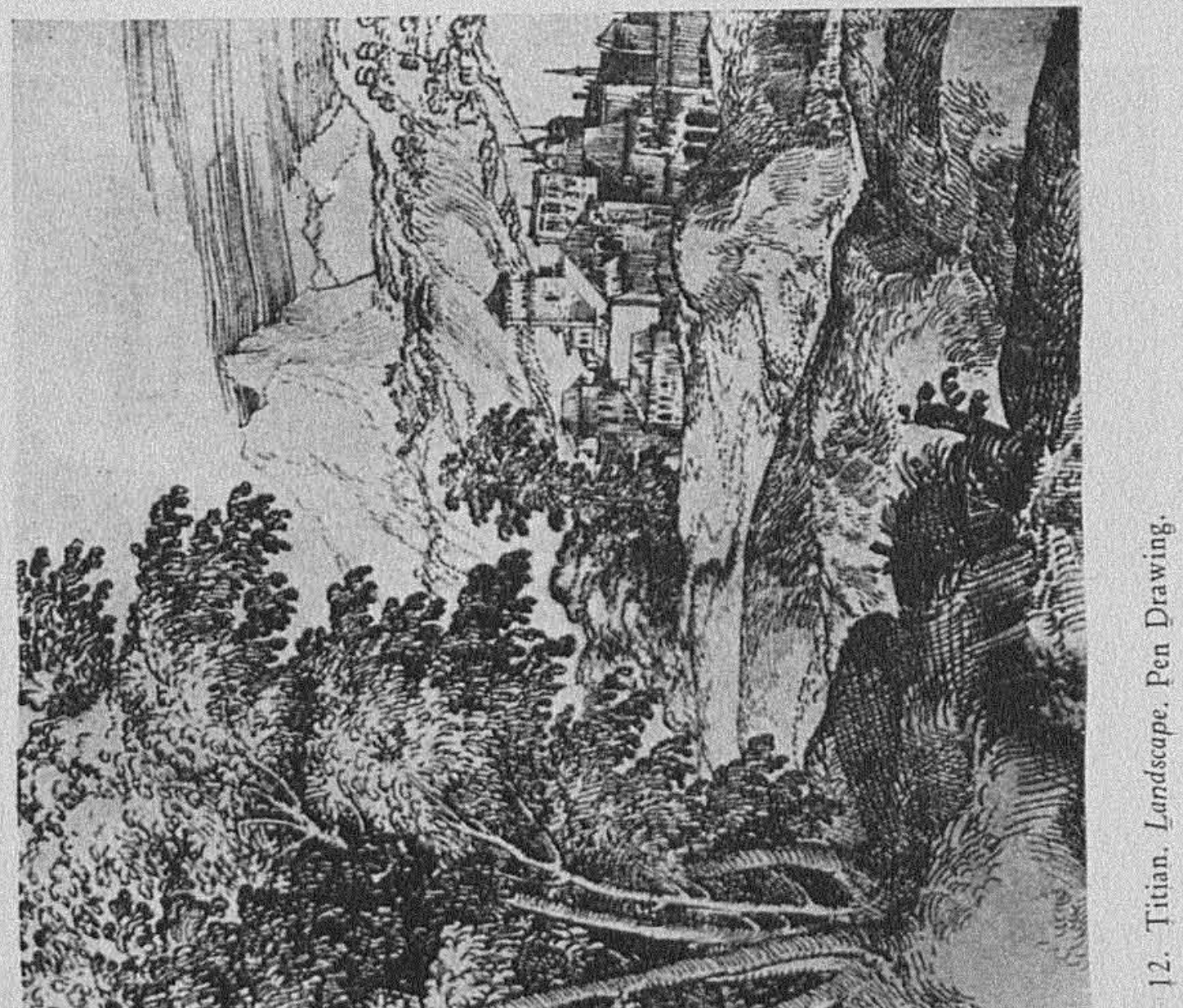

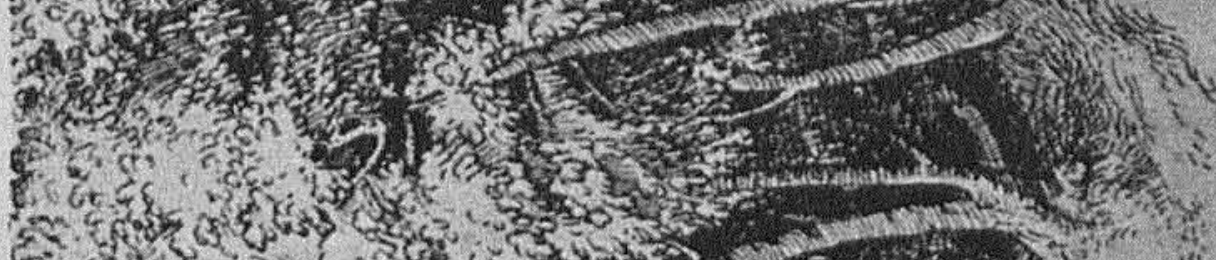

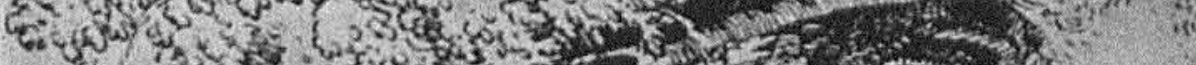

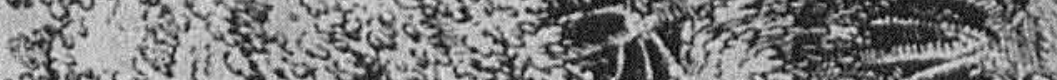
acticas

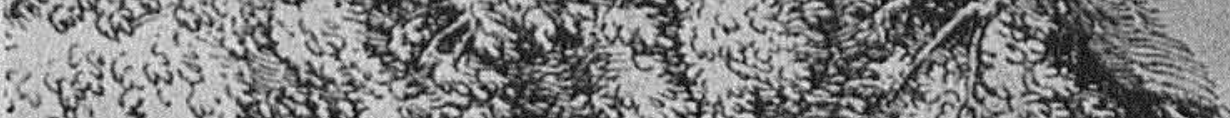

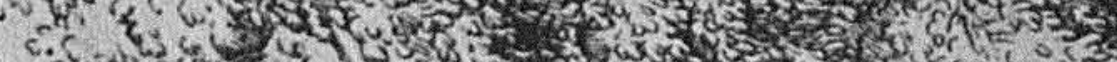

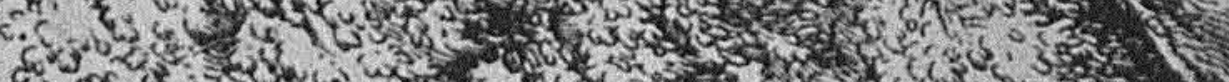

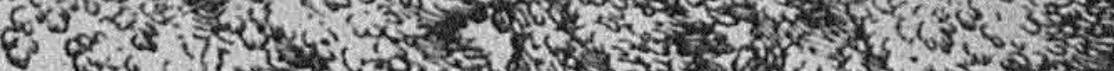

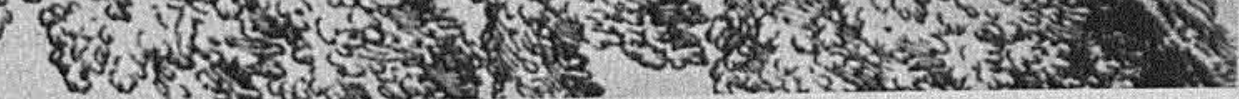




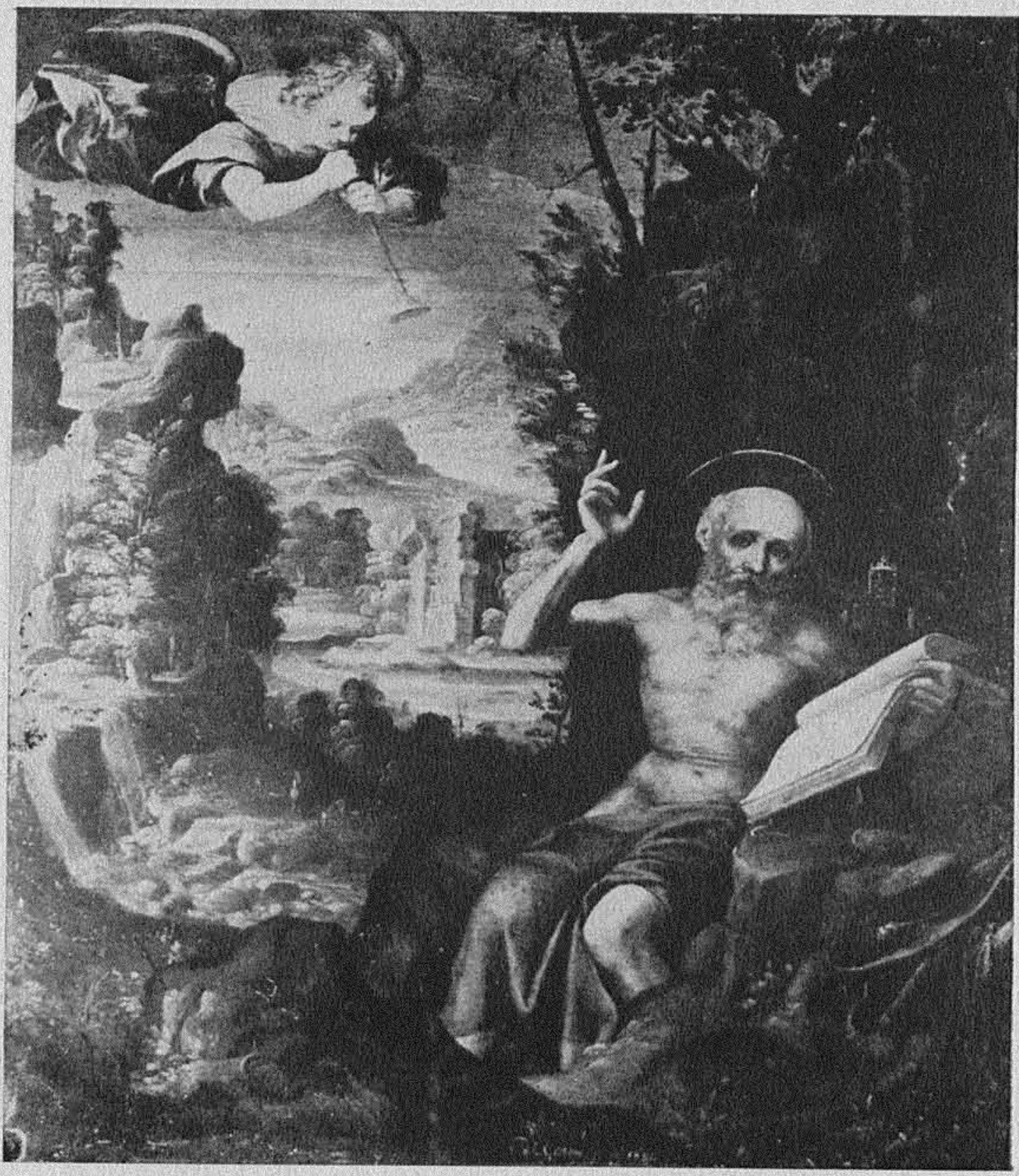

13. B. de Echave Ibía. St. Jerome-Galleries of S. Carlos. México. 


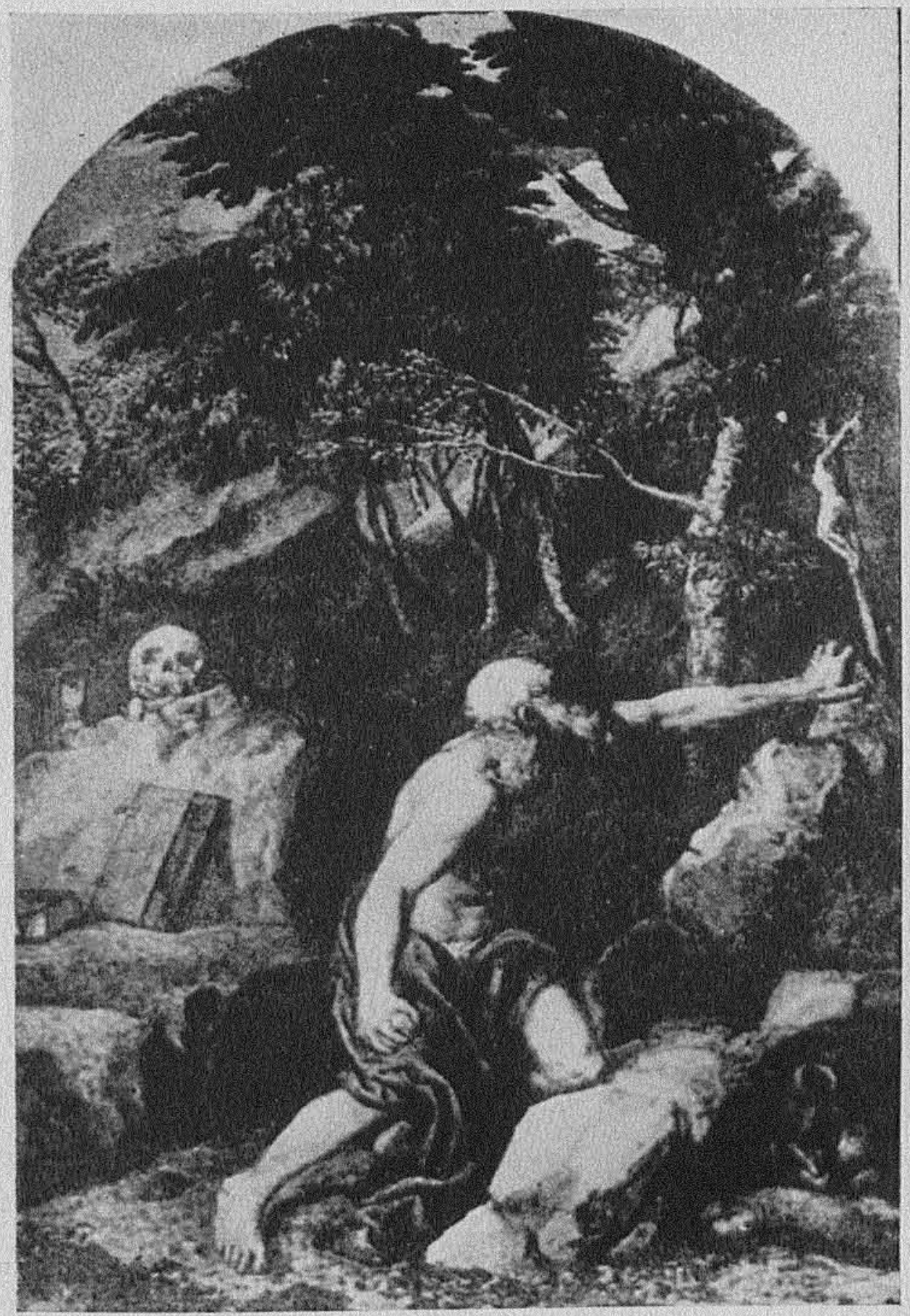

14. Titian. St. Jerome.-Brera Gallery. Milán. 


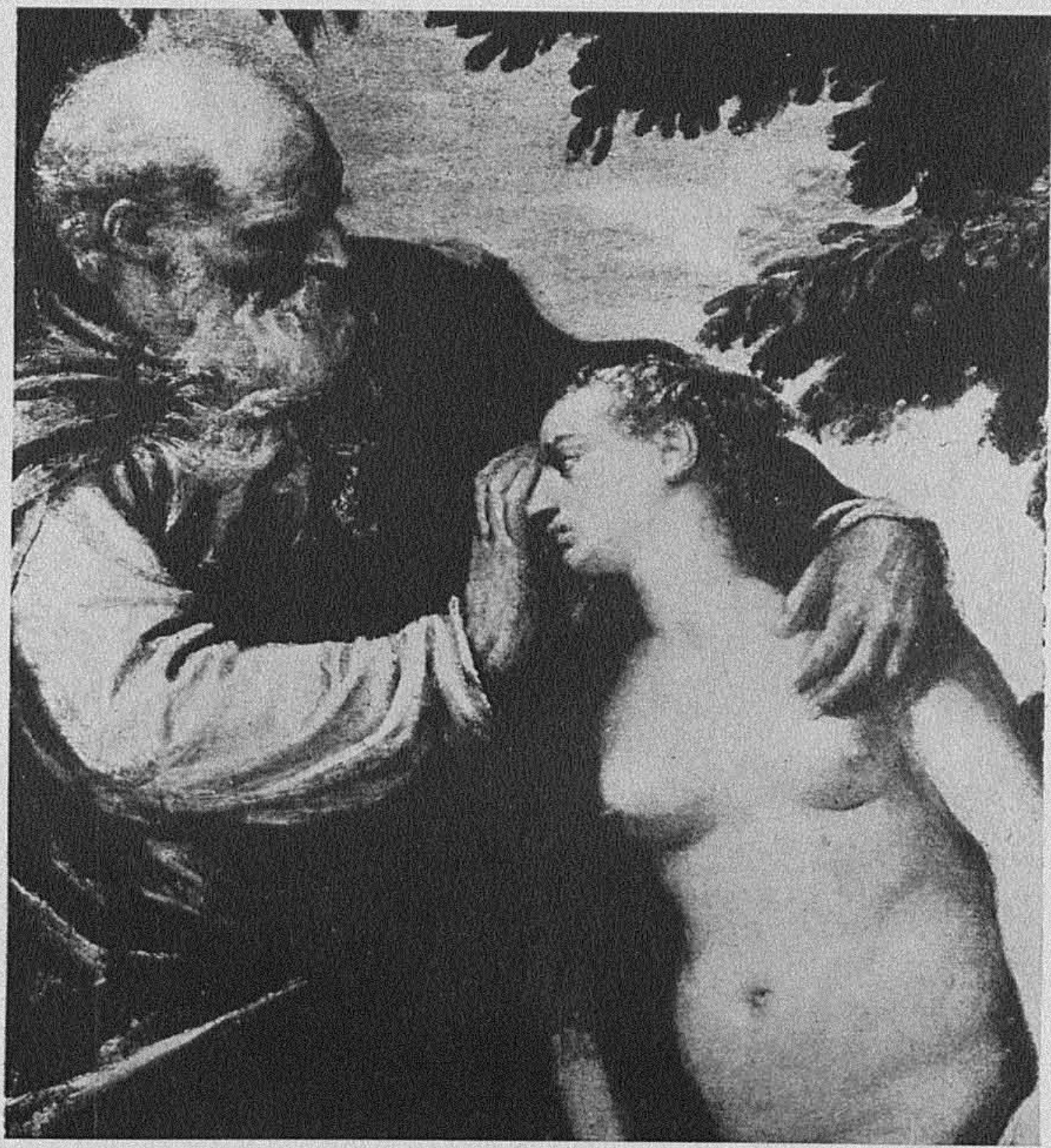

15. Veronese, Creation of Eve. Detail-W Worcester Collection, Art Institute of Chicago. (Photo. Art Institute of Chicago.) 
DOI: http://dx.doi.org/10.22201/iie.18703062e.1942.9.320

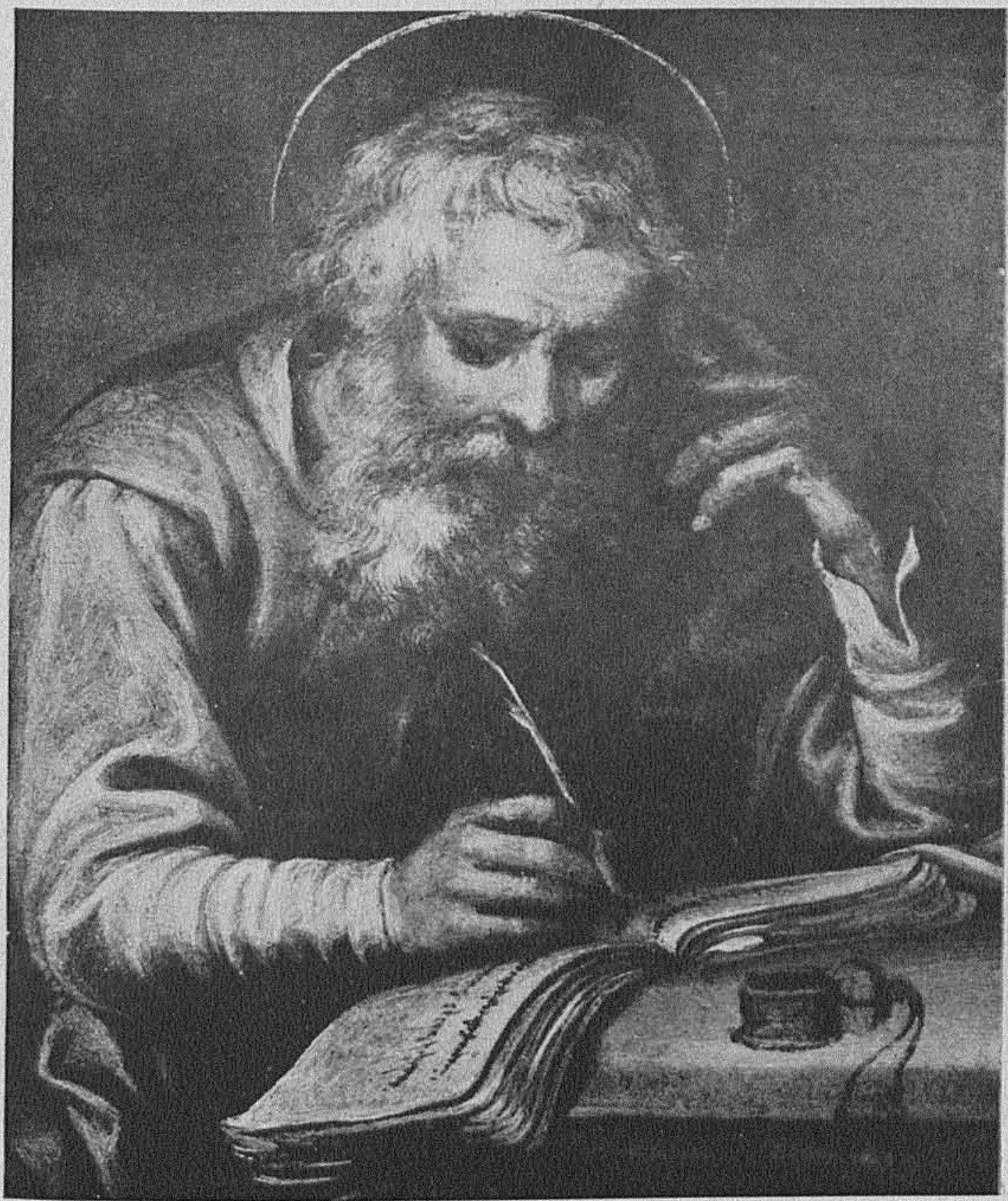

16. B. de Echave Ibia. St. Mark. Detail.-Collection of the Museum. Querétaro. 
DOI: http://dx.doi.org/10.22201/iie.18703062e.1942.9.320

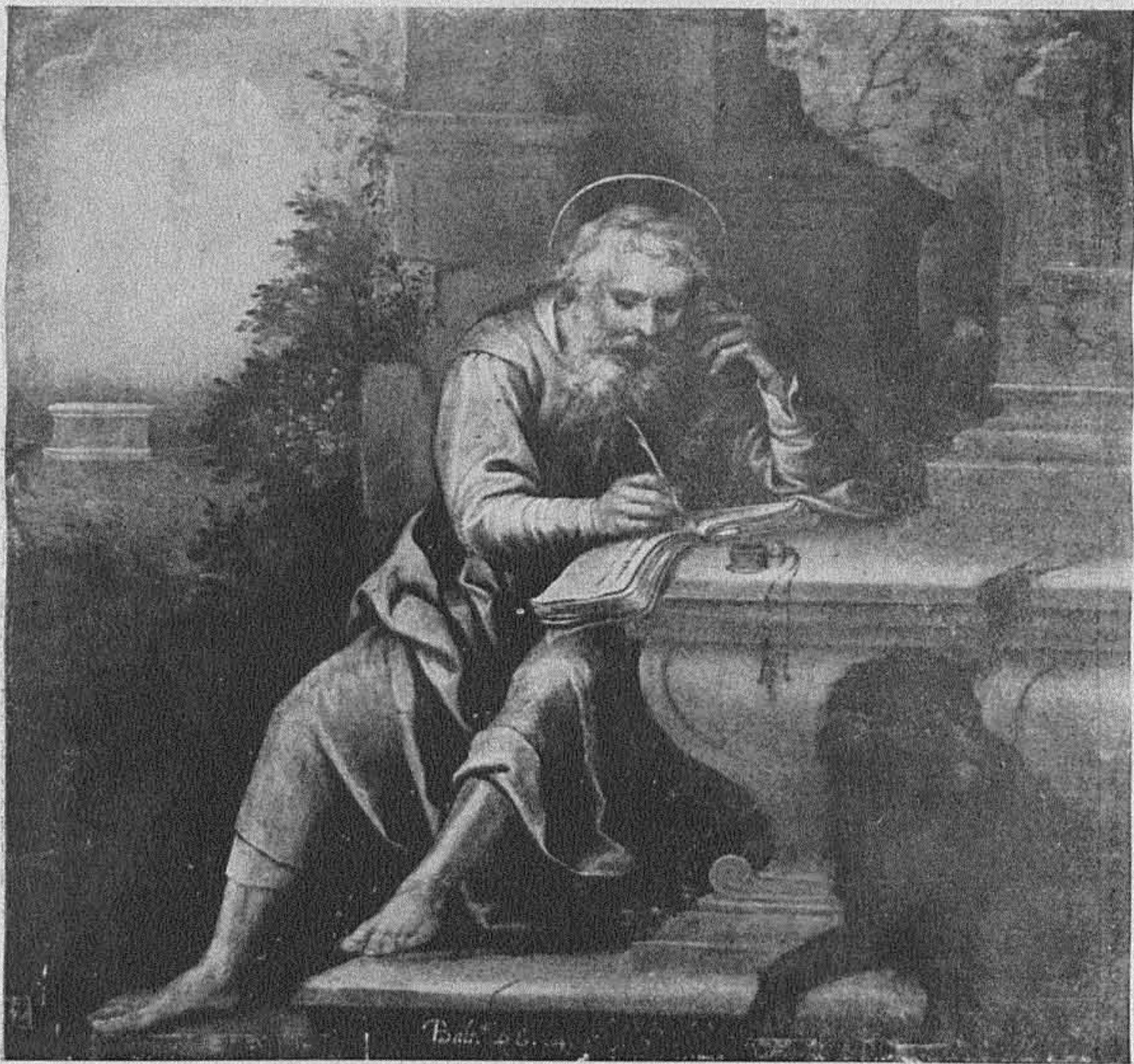

17. B. de Echave Ibía. St. Mark. Oil on copper-Collection of the Museum. Querétaro. 


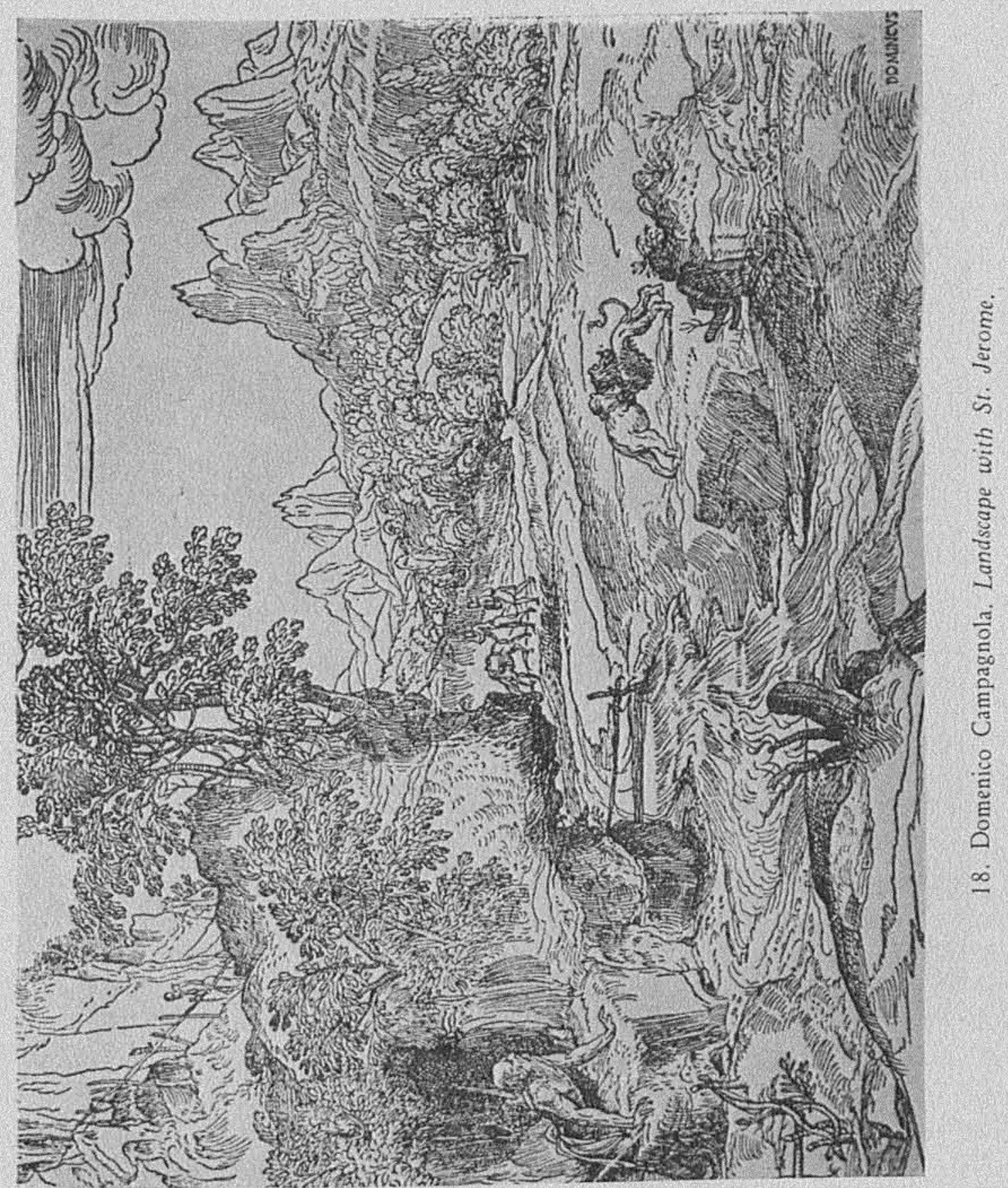




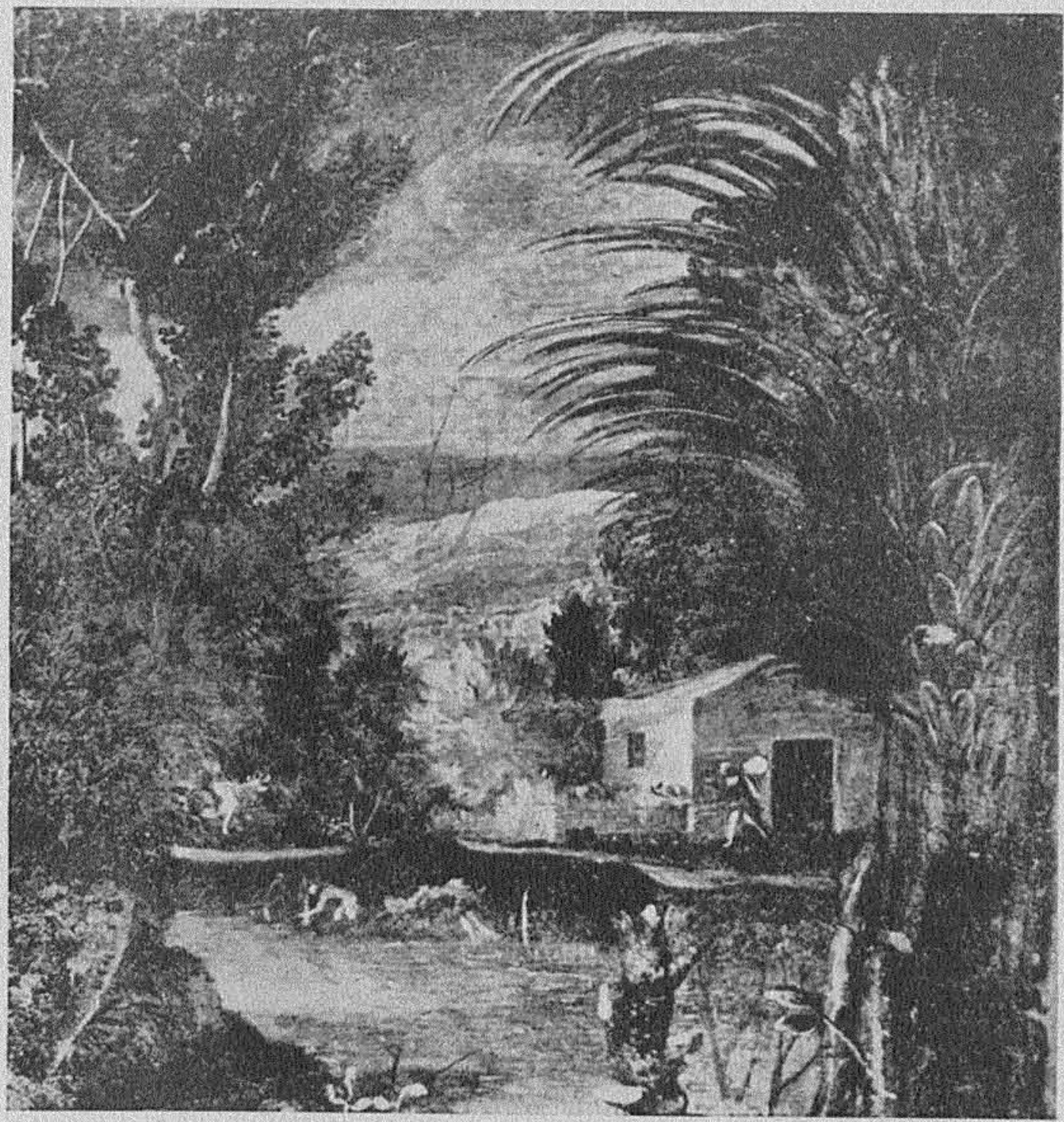

19. Tintoretto. Flight into Egypt. Background. Detail.-School of San Rocco. Venice. 
Echave Ibia's inability to handle more than one or two figures effectively may be seen. The two paintings are interesting because they indicate how much the artist depended upon engravings and European styles as a basis for his compositional schemes, instead of developing a purely personal style based upon his own observation and study of study of nature. These works are stilted and artificial in conception, a result to be expected when an artist lacks sufficient training or is going beyond his capacity for organizing complex arrangements of figure groups in space. These paintings afford, also, quite a contrast with majority of Ibia's other works which are much less ptetentiously conceived.

Echave Ibia, however, did a series of the Evangelists that are a delight to behold. Since they are all the same size, measuring fifteen inches square, and all painted on copper, it may be that they were a part of an altar-piece, or perhaps a larger framework ornament for a chapel: Thus far, I have not been able to ascertain exactly what their purpose was. The most beautifully painted is St. Joln the Evangelist. (Figs. 5,6 and 7.) In this, one can see how ably spatial qualities are controlled. His ability as a composer, making foreground and background integral, is at its best here. The design comes off in a perfectly natural way.

Each part, the large figure of St. John, the lanscape of the middle ground, and the baptismal scene in the distance, is arranged simply and expertly. In the foreground, the disposition of the figure upon a scheme of opposed diagonals is sustained by the arrangement of rock and tree forms in the middle distance, and these in turn serve as the frame for the figures and landscape in the background. An enlarged view of this scene shows what a complete thing it is apart, although it logically takes its place in the whole composition. It also shows clearly his vigorous, luminous handling of paint.

A detail of the figure of St. John (Fig. 6), shows an unmistakable Venetian quality to the tonality that is at once broad in pattern, yet minute and delicate in the transitions from light to dark. It is rather like the Venetian tradition reduced to an almost miniature scale. All of the slight graduation of nuance is strongly subordinated to the large organization, but the nuance is there to illuminate the lower tones and make the lights glowing and full. The realization of form is that of the painter; he draws with the brush and fuses color structure with that of the values. Color, of his own selection, plays a vital part in the movement of the light and shade. 
One can note here how Echave Ibia's drawing in a painterly sense has improved, particularly in the delineation of hands and the control of foreshortening. There is a grater sense of coordinate articulation between the small part and the larger areas. A view of the detail from the St. Mark of this same series reveals much the same character in the creation of form.

One of Echave Ibia's most interesting and complex compositions is that of the two hermit saints, St. Paul and St. Anthony (Figs. 8, 9, 10 y 11) in the wilderness. The story of the two saints meeting is one that has had an interesting history in the way it has been interpreted and presented by various painters. Lucas van Leyden, Pintorricchio, Sanchez Coello, Velasquez have all done different versions of this theme. Echave Ibia's handling of the story is one of the most delightful and one of the most integrated in the way he has presented the drama of the whole story of the meeting and the death of St. Paul.

For his conception he selects the two most important events in the story of the two hermits and brings them together in the same panel. This again is a small piece, measuring fifteen by twenty inches. In the foreground he depicts the two aged men after their conversation had been going on for several hours and the faithful raven is returning with a whole loaf of bread for them.

In the background the artist has told of the death of St. Paul. One sees St. Anthony returning to Paul's cave with the Bishop's cloak in which he was to wrap the body.

On his return when Anthony was about three hours distance from the cavern, he heard of a sudden the most ravishing music and looking up, he beheld the spirit of Paul, bright as a star and white as the driven snow, carried up to heaven by the prophets and apostles and a company of angels, who were singing hymns of triumph as they bore him through the air, until all had disappeared. Then he rose in haste and with all the speed he ran to the cave of Paul and found Paul dead in the attitude of prayer. ${ }^{5}$

By bringing these two events, the meeting and the death, together, Echave Ibia has given the work a dramatic unity that is closely connected with the pictorial division of foreground and background. The background is filled with picturesque crags and clouds and trees, but the distinct sense of unreality is charmingly effective as a part of the whole work.

This is one of his finest expression, particularly in the way in which the lovely minuteness of detail is treated without losing a sense of breacth.

5 A. JAMESON, Sacred and Legendary Art (Boston, 1895), Vol. II 
The traditional palm leaf mat that Paul wears is very carefully rendered, as are all of the fowl and animals placed about the foreground. An interesting comparison of another painter's treatment of the same theme is a painting by Sanchez Coello, showing St. Paul and St. Anthony conversing as the raven brings the loaf of bread. (Figs. 9 y 10.) One may note how the attitudes and gestures of the two men are much more closely related in the Ibia version, whereas Coello's handling is much more posed and artificial. Ibia makes a very compact grouping of the two figures by establishing the connecting axes with the arms and legs. Also the contrast in character between the two figures is most effectively conceived. The active, tense, and alert figure of Paul conversing and gesticulating is contrasted with the attentive, quiescent pose of St. Anthony. In this painting of Ibia's, there is very close relationship between the form and the idea; both are fused in a masterful way.

From the foregoing selected group of Echave Ibia's works, something of his development and the character of his style may be determined. Before making a summation of his stylistic qualities, it may be well to show examples from some European schools in order to indicate a few of the possible sources and antecedents that may have contributed to the development of Ibia's style. By seeing his works along with those of some of the great Italian painters, it may be possible to see Echave Ibia's art in a less isolated manner and to estimate his accomplishment more accurately.

There is still a great deal of work to be done on the problem of origins and sources that were actually used by the painters in Mexico. Because of this, I merely want to present these as likely, hypotheses, based upon the taste of the patrons at this time, the development of painting in Spain, the stylistic comparisons of the works themselves. This, I hope, will at least give a clearer concept of the achievement made by Ibia, if it does not offer conclusive proof as to the sources he used.

In showing these comparisons, I should like to make them, first, of a general nature, to indicate certain broader qualities that are similar; second, more specific in character, showing relationships in regards to technique, lighting, and brushwork.

Looking at Ibia's painting, St. Paul and St. Anthony in the Wilderness, again, along the Giovanni Bellini's St. Francis, from the Frick

6 European paintings of the same subject show St. Paul in a costume of a different weave. It is likely that Ibia got'his iden for St. Paul's costume from the typical Mexican petate. 
collection, one may detect certain general likennesses. In both, the landscape setting is dominant. Both, too, are works in which an exquisite sense of minute detail adds immeasurably to the decorative richness. There is in each painting a similarity in the subtlety of relationship between the figures and the natural setting. In the Bellini, it is idyllic; in the Ibia, it is romantic and dramatic. In both, the sensitively controlled patterns of light and dark play an important role. One cannot take such a comparison too far; it is being made chiefly as a suggestion. There is present, however, in this work by Ibia something of the decorative loveliness and lyricism that is found in the Bellini.

By comparing another small painting, St. Jerome (Fig. 13), by Ibia with different versions of the same theme by Titian (Fig. 14), some other general formal likeness may be seen. The effect of the lighting has much in common, also the use of dark masses, employed as a frame for the distant landscape vista. Again, as in Ibia's painting of St. John the Baptist, the landscape is less well related with the principal figure. But in the actual handling of transitions from light to dark, and in the brushwork, similarities can be perceived. This shows a rather fluent grasp of Venetian ideas, without, of course, the breadth and scope of Titian's expression.

A more intimate and revealing comparison may be made by showing the detail of Ibia's St. John the Evangelist (Fig. 6), with one from Veronese's Creation of Eve (Fig. 15), in the Worcester collection, Chicago. One sees how much Ibia has gained from the traditions of northern Italy. In both paintings, there is a very close feeling, particularly in the handling of drapery, and in the subtle progression of light through the half tones into dark. Ibia's thorough grasp of the plainter's metier shows clearly in the delicacy and refinement of his treatment of edges. Note how easily an accented linear edge will merge with the tonal pattern. Out of his handling of tone, he builds up a quality of atmosphere that is akin to the fused harmonies of the Venetians. This similarity is borne out in another detail taken from Ibia's St. Mark. (Fig. 16.) In both, the construction of form is in terms of the broad enveloping patterns of light and dark. The forms so constructed have strength and simplicity. Part of this comes from the sure placement of each object. It may be seen in the St. Mark. (Fig. 17.) All of the accessories are pulled into direct relation with the seated figure. It is to be noted, too, in the way hands, arms, and head are an integral part of the volumes moving in space. The likeness is also evident in the brushwork and the broad application of paint. Because of this, the surface quality of the paintings in very similar. 
The Venetian school is also very helpful in finding an analogous formal treatment of the landscape background. By comparing the landscape from the St. Paul and St. Anthony (Fig. 11), by Ibia with one of Titian's landscape drawings (Fig. 12), it is noticeable that the composite forms of hills and crags, the curving paths of light leading into the distance, are quite alike. This is also to be seen in the type of wood engraving by Campagnola (Fig. 18), that was so widely circulated in the sixteenth century. Here again one can see how the sixteenth century Venetian tradition could have been the source material for Ibia. One might stow here how effectively Ibia had established a strong movement on opposed diagonals, and how he emphasized spatial recession by vivid cross channels of lighting. This gives an indication of his grasp of abstract from by his free handling of light sources.

Another comparison, in regard to landscape, that may prove interesting is to show the background detail from Ibia's St. John the Evangelist (Fig. 7) with a detail from The Flight into Egypt by Tintoretto. (Fig. 19.) The likenesses are more generalized, but still the freedom of brushwork, the sharp lighting of edges of planes, and emphasis on movement are broadly related. It seems to give point and emphasis to Ibia's origins, if not exact proof.

Judging from the stylistic evidence, since it is the most reliable at this time, it seems to be most likely that Ibia's style was the result of strong Italianate influences, direct or indirect. Most of the standards of taste at the time of his father's development and the beginning of his own training were strongly affected by the styles and techniques of northern Italy. Even if Flemish influences did contribute toward his style, they also by this time would have been strongly Italianized. The picturesque landscape that Ibia employed had antecedents in a general way in a number of painters, Flemish and Italian, but the original source for Ibia was probably Italian. This conclusion is borne out as well in his technique and his drawing of the figure. Undoubtedly the engravings of Titian's landscapes, as well as those of his followers and contemporaries, were known in Mexico. There were also Venetian paintings there, too, but unfortunately $I$ cannot report at this time which ones Ibia might have seen.

These comparative examples by European painters may provide something of an indication as to the relative quality of Ibia's accomplishment. The Italianism present in his art did not hamper him, since he assimilated the ideas with little affectation or artificiality. His expression reflects sim- 
plicity and breadth. He possessed a sensibility that, if not grand, was surely one of the rarest to appear in Mexico during the colonial period. He possessed an exquisite sense of the art of painting, developing refinements of color and form that were his own.

He was limited, however, since most of his finest work is that which has only one or two figures set against the landscape background. Fortunately, perhaps, most of his work is devoted to the various santos, since he had little opportunity to work on the large commissions. In his characterization of the religious types, he attained a dramatic and lyric tone that is restrained and intimate. His religious figures are simple charaters beautifully painted. He used no over theatricality to mar the purity and directness of his expression. His painting reflects geniality, a delight in problems that a painter loves to solve. Through his paintings, Echave Ibia has provided us with one of the most felicitous moments in Mexican art. 